\title{
Effects of plant conduction systems and organic fertilizer management on disease incidence and severity in 'Osiana' and 'Carola' roses ${ }^{(1)}$
}

\author{
MÁRCIA DE NAZARÉ OLIVEIRA RIBEIRO*(2), ELKA FABIANA \\ APARECIDA ALMEIDA ${ }^{(2)}$, MARÍLIA ANDRADE LESSA(4), PEDRO MARTINS \\ RIBEIRO JÚNIOR(3), SÉRGIO SOARES BARBOSA(2), \\ JÚNIA RAFAEL MENDONÇA FIGUEIREDO(2), SIMONE NOVAES REIS(2)
}

\begin{abstract}
Conventional pruning is a very common practice for pruning rose cultivars in Brazil. However, few Brazilian producers known any other efficient plant training method for roses, namely "lateral stem bending" or "arching technique", which involves bending the branches of the rosebush in order to increase the photosynthetic rate of the plant. As well as plant training, the use of fertilizers must also be done carefully in order to obtain high quality roses. Biofertilizers are recommended because of their multiple effects: fertilizer, protein synthesis stimulant, insect repellent, and disease controller. The aim of this study was to assess the plant training system and management of organic fertilizer on the incidence and severity of disease in the 'Osiana' and 'Carola' roses. The 'Osiana' rosebushes received three concentrations $(0 \%, 5 \%$, and $15 \%)$ of foliar biofertilizer applied monthly to the leaves together with two plant conduction methods (conventional pruning and lateral stem bending). 'Carola' roses were treated with three types of fertilizer (chemical fertilizer on the soil + bokashi on the soil, chemical fertilizer on the soil + foliar Fishfertil and chemical fertilization on the soil without applying organic fertilizers) every two weeks, together with 2 plant conduction systems (conventional pruning and lateral stem bending). The additional treatments in 'Carola' roses were composed of two organic fertilizers (Bokashi and foliar Fishfertil ${ }^{\circledR}$ ) and chemical fertilization with lateral pruning. The incidence and severity of disease in these plants during the experiment were assessed over 5 months. For the 'Osiana' rose, the incidence and severity of disease were not influenced by fertilizer management or plant training methods. For the 'Carola' roses, the different types of fertilizer caused different responses according to the plant training system used, with the biofertilizer Fishfertil ${ }^{\circledR}$ reducing the incidence of powdery mildew when applied to plants with laterally bent stems.
\end{abstract}

Keywords: Floriculture, roses, biofertilizers, downy mildew, powdery mildew.

\section{RESUMO \\ Sistemas de condução da planta e manejo da adubação orgânica na incidência e severidade de doenças em roseiras 'Osiana' e 'Carola'}

A poda convencional é uma prática muito comum nos cultivos de rosas para corte no Brasil. Porém, poucos produtores brasileiros têm conhecimento de outra forma eficiente de condução do roseiral denominada de agobio que consiste em dobrar os ramos da roseira com o intuito aumentar a taxa fotossintética da planta. Além do sistema de condução, a adubação da roseira também precisa ser criteriosa para obtenção de rosas de qualidade. Dentre os adubos, os biofertilizantes são recomendados por seus múltiplos efeitos: fertilizante, estimulante da proteossíntese, repelente de insetos e controlador de doenças. O objetivo deste estudo foi avaliar o efeito do sistema de condução da planta e o manejo da adubação orgânica na incidência e severidade de doenças em roseiras 'Osiana' e 'Carola'. As roseiras 'Osiana' receberam 3 porcentagens do biofertilizante 'Supermagro' aplicado mensalmente via foliar $(0 \%, 5 \%$, e $15 \%$ ) em combinação com 2 formas de condução da planta (utilização de poda convencional e de agobio). Plantas da cultivar Carola, foram submetidas a tratamentos constituídos de 3 tipos de adubação (adubação química no solo + bokashi no solo, adubação química + Fishfertil ${ }^{\circledR}$ foliar e adubação química sem aplicação de adubos orgânicos) aplicados quinzenalmente, em combinação com 2 formas de condução da planta (utilização de poda convencional e agobio). O tratamento adicional neste experimento foi constituído pelos dois adubos orgânicos e a adubação química associada ao agobio. Avaliou-se a incidência e severidade de doenças nas plantas desses experimentos durante 5 meses. Para a cultivar Osiana, a incidência e severidade de doenças não foram influenciadas pelo manejo da adubação e pelo sistema de condução da planta. Para a cultivar Carola os tipos de adubação resultaram em respostas distintas em função do sistema de condução da planta, sendo que o biofertilizante Fishfértil ${ }^{\circledR}$, quando aplicado nas plantas conduzidas no sistema de agobio reduz a incidência de oídio. Palavras-chave: Floricultura, rosas, biofertilizantes, míldio, oídio.

\footnotetext{
(1) Trabalho recebido para publicação em 13/07/2011 e aprovado em 22/10/2014

(2) Empresa de Pesquisa Agropecuária de Minas Gerais (EPAMIG), Avenida Visconde de Rio Preto, s/n. Bairro Vila São Paulo (Fábricas), CEP: 36301-360, São João Del Rei-MG.*Autor correspondente: marcia 162@hotmail.com

(3) Universidade Federal de Lavras (UFLA), Departamento de Fitopatologia, Campus Universitário, Caixa Postal 3037, CEP: 37200-000, Lavras-MG

(4) Universidade de Brasília (UnB), Faculdade de Agronomia e Medicina Veterinária (FAV), campus universitário Darcy Ribeiro, Asa Norte, BrasíliaDF, CEP 70910-900.
} 


\section{INTRODUCTION}

The rosebush is currently one of the most used flowering plants in the world and is marketed both within and beyond Brazil. They have romantic connotations and are widely appreciated for their variety of colors, aromas, and forms (ALMEIDA et al., 2014).

Currently, Brazilian producers have been concerned with improving production, logistics, and post-harvest processes, in an attempt to offer a high-quality product (MARTINEZ, 2007). To produce high-quality roses, the plant must be trained correctly. Traditional pruning allows all the branches to grow after the seedlings are planted to promote essential carbohydrate accretion, which will be used to form basal branches. In seedlings grown in the field for approximately one month and have a strong primary branch of approximately $1 \mathrm{~cm}$ in diameter, this branch must be cut to $40 \mathrm{~cm}$ from the ground. After several days, the primary branch will produce several secondary branches. The secondary branches must be selectively pruned leaving a maximum of 2 to 3 on each primary branch. The secondary branches must be vigorous and cut to a height of $20 \mathrm{~cm}$ from the primary branch. The flower stalks, which will be marketed, grow from these secondary branches (ALMEIDA et al., 2014).

Besides traditional pruning, there is another training method for rose bushes that is described as lateral stem bending or arching technique. This method is already widely used in many European countries, and in the United States, Africa, and has recently been adopted in some Brazilian states. The term "agobio" (bending the plant) has a Spanish origin and means a load or weight in the branches. The term "agobio" (bending the plant), also known as "Japanese bending", is a plant training method for roses, which comprises bending over fine branches in the early stages of development, and leaving intact the thick basal braches of the plant. This allows retention of leaves in the thicker, heavier basal branches, which continue to generate photosynthetic assimilates used to produce buds, increasing productivity and quality of flower stalks (LIETH and KIM, 2001).

Besides plant training methods, the use of fertilizer and the control of pests and disease are also essential for the cultivation of roses in protected environments. Vida et al. (2004) and Zambolim et al. (1999) conducted research on the control of disease in plants in protected environments and observed that management strategies that aim to reduce initial inoculation and reduce the progression of disease must be followed. This means that, as well as multiple application of appropriate control measures, it is necessary to act on all components of the production chain (soil preparation, selection of crops and hybrids, fertilizers, irrigation, cultivation, pest management, etc.), aiming to optimize each to obtain the maximum production potential of the crop and to reduce the severity of disease.

Using organic compounds together with or instead of inorganic fertilizers is not only economically advantageous but also conserves the physical and chemical properties of the soil (SOUZA, 1998). Biofertilizers are bioactive compounds, the final by-product of the fermentation of organic compounds, containing live or latent cells of microorganisms (bacteria, yeast, algae, and filamentous fungi) and its metabolites, as well as organic-inorganic chelates. They are produced in biodigesters through aerobic and/or anaerobic fermentation of organic matter. These compounds are rich in enzymes, antibiotics, vitamins, toxins, phenols, esters, and acids, with phytohormonal properties. Besides the already well-established nutritional effects, biofertilizers are also known for their ability to induce disease resistance, as well as their fungicidal, bacteriostatic, repellent, insecticidal, and miticidal properties (MEDEIROS et al., 2012).

The effects of biofertilizers on the control of plant pests and disease have been widely documented. Fungistatic and bacteriostatic properties and repellent effects on insects have already been found in some species. For example, Cunha et al. (2000) found less powdery mildew on bean plants treated with different mixtures of biofertilizers. For rosebushes, there is no scientific information about the effects organic fertilizers and pruning or lateral stem bending on the incidence of disease. Therefore, the aim of this study was to assess the effect of plant training methods and organic fertilizer management on the incidence and severity of disease in 'Osiana' and 'Carola' roses.

\section{MATERIALS AND METHODS}

Two experiments were carried out in a greenhouse without climate control, covered with a plastic diffuser on top and $50 \%$ shade cloth on the sides, located $889 \mathrm{~m}$ above sea-level $\left(21^{\circ} 06^{\prime} \mathrm{S} 44^{\circ} 15^{\prime} \mathrm{W}\right)$. The regional climate is temperate, with a wet summer and dry winter. The average annual temperature is $19.2^{\circ} \mathrm{C}$ with a minimum temperature of $5^{\circ} \mathrm{C}$ (July) and maximum of $37^{\circ} \mathrm{C}$ (February); the wet season is between October-April, with a total of $1,400 \mathrm{~mm}$ of annual rainfall.

\section{Bending assessment in the 'Osiana' rose}

'Osiana' rose seedlings, produced using the cutting method were planted in a 11 liter pot containing a substrate composed of ravine soil (Type 3 soil-Clay texture) (Table 1), $3 \mathrm{~kg}$ of cattle manure, $40 \mathrm{~g}$ of Yoorin ${ }^{\circledR}$ and $120 \mathrm{~g}$ of lime. Two seedlings were planted in each pot. 
Table 1. Chemical composition of soil used as substrate for cultivating 'Osiana' and 'Carola' rosebushes. São João del Rei, MG.

Tabela 1. Composição química do solo utilizado na formulação do substrato de plantio de roseiras 'Osiana' e 'Carola' cultivadas em vaso. São João del Rei, MG.

\begin{tabular}{c|c|c|c|c|c|c|c|c|c|c|c|c|c|c|c|c|}
$\mathbf{p H}$ & $\mathbf{P}$ & $\mathbf{K}$ & $\mathbf{Z n}$ & $\mathbf{F e}$ & $\mathbf{M n}$ & $\mathbf{C u}$ & $\mathbf{B}$ & $\mathbf{S}$ & $\mathbf{C a}$ & $\mathbf{M g}$ & $\mathbf{A l}$ & $\mathbf{H}+\mathbf{A l}$ & $\mathbf{S B}$ & $\mathbf{V}$ & $\mathbf{M O}$ \\
$\mathbf{( 1 : 2 , 5 )}$ & \multicolumn{9}{|c|}{$\mathbf{m g} \cdot \mathbf{d m}^{-3}$} \\
\hline 6,1 & 3,7 & 73 & 7,9 & 66,5 & 27,1 & 7,4 & 0,1 & 12,8 & 3,2 & 0,6 & 0,1 & 2,9 & 4,0 & 57,9 & 2,0 \\
\hline
\end{tabular}

MO = Matéria orgânica, SB = Soma de bases trocáveis, V = Saturação de bases

The experimental design was a randomized block, with a factorial treatment structure $(2 \times 3)$ totaling six treatments and four replications per treatment. The treatments constituted two plant training methods (conventional pruning and lateral stem bending) together with three doses of "Supermagro" biofertilizer $(0 \%, 5 \%$, and 15\%). "Supermagro" was prepared according to the methodology of VENZON et al. (2006) and applied, monthly, to the leaves. The results of the chemical analysis of "Supermagro" are presented in Table 2.

Table 2. Chemical composition of the biofertilizer "Supermagro" used in foliar sprays on 'Osiana' rosebushes cultivated in a pot. São João del Rei, MG.

Tabela 2. Composição química do biofertilizante "Supermagro" utilizando nas pulverizações foliares em rosas 'Osiana' cultivadas em vaso. São João del Rei, MG.

\begin{tabular}{|c|c|c|c|c|c|c|c|c|c|c|c|c|c|}
\hline $\begin{array}{c}\text { Density } \\
\text { g.cm-3 }\end{array}$ & $\mathbf{N}$ & $\mathbf{P}$ & $\mathbf{K}$ & $\mathbf{C a}$ & $\mathbf{M g}$ & $\mathbf{S}$ & $\mathbf{B}$ & $\mathbf{C u}$ & $\mathbf{M n}$ & $\mathbf{Z n}$ & $\mathbf{F e}$ \\
\hline 1,02 & 2,9 & 1,9 & 15,5 & 29,0 & 22,1 & 27,2 & 20,8 & 5,33 & 8,32 & 42,17 & 4,54 \\
\hline
\end{tabular}

\section{Bending method in the 'Carola' rose}

A seedling of the 'Carola' rose was planted in each 8-liter pot with a substrate composed of ravine soil (Type 3 soil -Clay texture) (Table 1). The experimental design was a randomized block, with a $3 \times 2$ factorial treatment structure and 1 additional treatment, totaling seven treatments and four replications per treatment. The treatments involved three types of fertilizer (chemical fertilizer on the soil + bokashi on the soil, chemical fertilizer on the soil + foliar Fishfertil and chemical fertilizer on the soil without applying organic fertilizers) applied every two weeks using two plant training methods (conventional pruning and lateral pruning). The additional treatment was composed of the two organic fertilizers (bokashi applied onto the soil + Fishfertil ${ }^{\square}$ applied to the leaves) used simultaneously, and chemical associated with lateral stem bending.

\section{Tests}

For both experiments, when the plants were in production (six months after planting) weekly samples were taken of leaflets of the central leaves of the productive branch of each plant to assess the incidence and severity of downy mildew (Peronospora sparsa), powdery mildew (Sphaerotheca pannosa) and rose black spot (Diplocarpon rosae). The incidence was determined by the presence and absence of damaged leaves in the experimental unit. To assess the disease severity, diagrammatic scales proposed by PASINI et al. (1997) were used. The average rates of incidence and severity observed were transformed into area under the severity progress curve (AUSPC) and incidence progress curve (AUIPC), determined using the equation proposed by Shaner and Finney (1977). The assessment period took place between April and September 2011.

\section{RESULTS AND DISCUSSION}

It was observed that the incidence and severity of disease in rosebushes was influenced by plant training method and addition of organic fertilizers (Tables 3, 4, and 5). Rose blackspot did not occur, which confirms what Gomes (2005) found; there is a low probability of developing this disease in greenhouse environments.

In experiment 1 , there was no significant difference between treatments with regard to both incidence and severity of powdery mildew and downy mildew on Osiana roses. The two plant-training techniques, conventional pruning or lateral stem bending, did not influence the results. Spraying the biofertilizer "Supermagro," recommended for nutrition and prevention and control of disease in plants, did not efficiently reduce severity and incidence of powdery and downy mildew (Table 3). 
Table 3. Effect of treatments on the area under the curve of the severity progress (AACPS) and incidence (AACPI) of powdery mildew and downy mildew on rose culture 'Osiana'. São João del Rei, MG.

Tabela 3. Efeito dos tratamentos na área abaixo da curva do progresso da severidade (AACPS) e da incidência (AACPI) do oídio e míldio na cultura da roseira 'Osiana'. São João del Rei, MG.

\begin{tabular}{|c|c|c|c|c|c|c|}
\hline \multirow{4}{*}{$\begin{array}{l}\text { "Supermagro" } \\
\text { biofertilizer }\end{array}$} & \multicolumn{6}{|c|}{ Downy mildew } \\
\hline & \multicolumn{3}{|c|}{ AUSPC } & \multicolumn{3}{|c|}{ AUIPC } \\
\hline & \multicolumn{2}{|c|}{ Plant training methods } & & \multicolumn{2}{|c|}{ Plant training methods } & \multirow[b]{2}{*}{ Means } \\
\hline & Conventional pruning & $\begin{array}{l}\text { Lateral stem } \\
\text { bending }\end{array}$ & Means & Conventional pruning & $\begin{array}{l}\text { Lateral stem } \\
\text { bending }\end{array}$ & \\
\hline $0 \%$ & 5,09 & 4,92 & 5,01 & 10290,00 & 11506,25 & 10898,13 \\
\hline $5 \%$ & 6,20 & 3,31 & 4,76 & 12509,58 & 10797,50 & 11653,54 \\
\hline $15 \%$ & 4,50 & 3,88 & 4,19 & 10791,67 & 10529,17 & 10660,42 \\
\hline Means & 5,26 & 4,04 & & 11197,08 & 10944,31 & \\
\hline \multirow{4}{*}{$\begin{array}{l}\text { "Supermagro" } \\
\text { biofertilizer }\end{array}$} & \multicolumn{6}{|c|}{ Powdery mildew } \\
\hline & \multicolumn{3}{|c|}{ AUSPC } & \multicolumn{3}{|c|}{ AUIPC } \\
\hline & \multicolumn{2}{|c|}{ Plant training methods } & & \multicolumn{2}{|c|}{ Plant training methods } & \\
\hline & Conventional pruning & $\begin{array}{l}\text { Lateral stem } \\
\text { bending }\end{array}$ & Means & Conventional pruning & $\begin{array}{l}\text { Lateral stem } \\
\text { bending }\end{array}$ & Means \\
\hline $0 \%$ & 5,02 & 4,80 & 4,91 & 9983,75 & 10806,25 & 10395,00 \\
\hline $5 \%$ & 6,20 & 3,28 & 4,74 & 12115,83 & 10710,00 & 11412,92 \\
\hline $15 \%$ & 4,35 & 3,75 & 4,05 & 9960,42 & 9654,17 & 9807,29 \\
\hline Means & 5,19 & 3,94 & & 10686,67 & 10390,14 & \\
\hline
\end{tabular}

'Supermagro' is a liquid organic fertilizer described as a natural defense agent as it is a growth medium for beneficial bacteria, mainly Bacillus subtilis, which inhibits the growth of fungi and bacteria that cause disease in plants, as well as increasing insect and mite resistance (PEDINI, 2000).

The results observed for the Carola crop revealed that, under the experimental conditions used in this study, the use of fertilizers and plant training methods interfered with the incidence and severity of powdery and downy mildew. As shown in Table 4, the highest incidence of powdery mildew was found on plants that were not treated with organic fertilizer and were cultivated by conventional pruning. For the plants that were cultivated by lateral stem bending, there was a higher incidence of powdery mildew in plants treated with organic fertilizer, whereas, in traditionally pruned plants, there was no difference between the types of fertilizer tested. With regard to severity of powdery mildew, there was no significant difference between treatments. These results were consistent with those by Patriquin et al., (1993) who claim that the type of fertilizer influences the occurrence of pests and disease in various cultivated plants.

With conventional pruning, there was a greater severity of downy mildew in plants that were not treated with organic fertilizers, whereas, plants cultivated with lateral stem bending had a greater incidence and severity of disease when the organic fertilizer bokashi was used. However, traditionally pruned plants showed a higher incidence of downy mildew only when chemical fertilizer was applied. The incidence of downy mildew was not influenced by plant training methods when the product Fishfertil ${ }^{\circledR}$ was used as an organic leaf fertilizer (Table 5). 
Table 4. Effect of treatments on the area under the curve of the severity progress (AACPS) and incidence (AACPI) of powdery mildew and downy mildew on rose culture 'Carola'. São João del Rei, MG.

Tabela 4. Efeito dos tratamentos na área abaixo da curva do progresso da severidade (AACPS) e da incidência (AACPI) do oídio e míldio na cultura da roseira 'Carola'. São João del Rei, MG.

\begin{tabular}{|c|c|c|c|c|c|c|}
\hline \multirow{4}{*}{ Treatments } & \multicolumn{6}{|c|}{ Downy mildew } \\
\hline & \multicolumn{3}{|c|}{ AUSPC } & \multicolumn{3}{|c|}{ AUIPC } \\
\hline & \multicolumn{2}{|c|}{ Plant training methods } & & \multicolumn{2}{|c|}{ Plant training methods } & \multirow[b]{2}{*}{ Means } \\
\hline & Conventional pruning & $\begin{array}{l}\text { Lateral stem } \\
\text { bending }\end{array}$ & Means & Conventional pruning & $\begin{array}{l}\text { Lateral stem } \\
\text { bending }\end{array}$ & \\
\hline Bokashi & 7,92 & 11,79 & $9,85 \mathrm{~A}$ & 10278,33 a A & 11586,46 a B & 10932,40 \\
\hline Fishfertil $^{\circledR}$ & 11,20 & 12,60 & $11,90 \mathrm{~A}$ & 12191,67 a A & 11147,50 a B & 11669,58 \\
\hline Chemical fertilization & 13,97 & 12,66 & $13,32 \mathrm{~A}$ & 12419,17 b A & 9934,17 a A & 11176,67 \\
\hline Means & $11,03 \mathrm{a}$ & $12,35 \mathrm{a}$ & & 11629,72 & 10889,38 & \\
\hline \multirow{4}{*}{ Treatments } & \multicolumn{6}{|c|}{ Powdery mildew } \\
\hline & \multicolumn{3}{|c|}{ AUSPC } & \multicolumn{3}{|c|}{ AUIPC } \\
\hline & \multicolumn{2}{|c|}{ Plant training methods } & & \multicolumn{2}{|c|}{ Plant training methods } & \\
\hline & Conventional pruning & $\begin{array}{l}\text { Lateral stem } \\
\text { bending }\end{array}$ & Means & Conventional pruning & $\begin{array}{l}\text { Lateral stem } \\
\text { bending }\end{array}$ & Means \\
\hline Bokashi & 3,18 a A & $12,50 \mathrm{~b} \mathrm{~B}$ & 7,84 & 7910,00 a A & 9467,50 b B & 8688,75 \\
\hline Fishfertil $^{\circledR}$ & 5,10 a A & 5,51 a A & 5,30 & 9753,33 a A & 8758,75 a A & 9256,04 \\
\hline Chemical fertilization & 10,62 a B & 5,42 a A & 8,02 & $11649,17 \mathrm{~b} \mathrm{~A}$ & 10182,08 a C & 10915,63 \\
\hline Means & 6,30 & 7,81 & & 9770,83 & 9469,44 & \\
\hline
\end{tabular}

Means with the same letter, lowercase on the rows and uppercase in the columns, do not differ significantly between one another with the Tukey test $(\mathrm{P} \leq 0.05)$.

Table 5. Comparison of the effect of treatments on the area under the curve of severity progress (AACPS) and incidence (AACPI) of powdery mildew and downy mildew on rose culture 'Carola' with additional treatment. São João del Rei, MG. Tabela 5. Comparação do efeito dos tratamentos na área abaixo da curva do progresso da severidade (AACPS) e da incidência (AACPI) do oídio e míldio na cultura da roseira 'Carola' com o tratamento adicional. São João del Rei, MG.

\begin{tabular}{|c|c|c|c|c|}
\hline \multirow{4}{*}{ Treatments } & \multicolumn{4}{|c|}{ Downy mildew } \\
\hline & \multicolumn{2}{|c|}{ AUSPC } & \multicolumn{2}{|c|}{ AUIPC } \\
\hline & \multicolumn{2}{|c|}{ Plant training methods } & \multicolumn{2}{|c|}{ Plant training methods } \\
\hline & Conventional pruning & Lateral stem bending & Conventional pruning & Lateral stem bending \\
\hline Bokashi & $9,86^{\mathrm{ns}}$ & $12,03^{\mathrm{ns}}$ & $12064,79^{\mathrm{ns}}$ & $10769,79^{\mathrm{ns}}$ \\
\hline Fishfertil $^{\circledR}$ & $10,99^{\mathrm{ns}}$ & $11,52^{\mathrm{ns}}$ & $11039,58^{\mathrm{ns}}$ & $10778,54^{\mathrm{ns}}$ \\
\hline $\begin{array}{l}\text { Chemical } \\
\text { fertilization }\end{array}$ & $13,90^{\mathrm{ns}}$ & $10,88^{\mathrm{ns}}$ & $11585,00^{\mathrm{ns}}$ & $11398,33^{\mathrm{ns}}$ \\
\hline \multirow{2}{*}{ Additional } & \multicolumn{2}{|c|}{11,63} & \multicolumn{2}{|c|}{10718,75} \\
\hline & \multicolumn{4}{|c|}{ 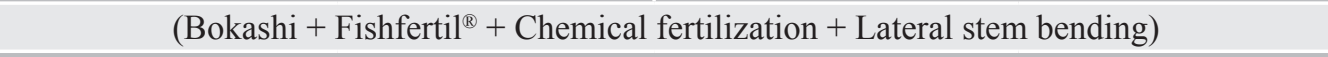 } \\
\hline \multirow{4}{*}{ Treatments } & \multicolumn{4}{|c|}{ Powdery mildew } \\
\hline & \multicolumn{2}{|c|}{ AUSPC } & \multicolumn{2}{|c|}{ AUIPC } \\
\hline & \multicolumn{2}{|c|}{ Plant training methods } & \multicolumn{2}{|c|}{ Plant training methods } \\
\hline & Conventional pruning & Lateral stem bending & Conventional pruning & Lateral stem bending \\
\hline Bokashi & $3,18^{*}$ & $12,50^{\mathrm{ns}}$ & $7910,00^{\mathrm{ns}}$ & $9467,50^{\text {ns }}$ \\
\hline Fishfertil $^{\circledR}$ & $5,10^{\mathrm{ns}}$ & $5,51^{\mathrm{ns}}$ & $9753,33^{\text {ns }}$ & $8758,75^{\text {ns }}$ \\
\hline $\begin{array}{l}\text { Chemical } \\
\text { fertilization }\end{array}$ & $10,62^{\mathrm{ns}}$ & $5,42^{\text {ns }}$ & $11649,17^{\mathrm{ns}}$ & $10182,08^{\mathrm{ns}}$ \\
\hline \multirow{2}{*}{ Additional } & \multicolumn{2}{|c|}{6,63} & \multicolumn{2}{|c|}{10412,50} \\
\hline & \multicolumn{4}{|c|}{ 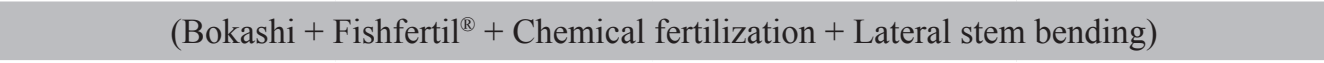 } \\
\hline
\end{tabular}

* = significant with the Dunnett test $(\mathrm{P} \leq 0.05) ; \mathrm{ns}=$ not significant with the Dunnett test $(\mathrm{P} \leq 0.05)$. 
There was no significant difference between the types of fertilizer tested on the incidence of downy mildew when the plants were traditionally pruned. However, when plants were cultivated by lateral stem bending, a higher incidence occurred without the application of organic fertilizers and a lower incidence occurred when the product Fishfertil ${ }^{\circledR}$ was applied (Table 4).

According to Pereira et al., (1996) the use of organic compounds is an effective technique for managing pathogens. As well as the beneficial effect on the physicochemical characteristics of the soil, the organic compounds diminish populations of pathogens and plant pests (HOITINK and BOHEM, 1991 cited by PEREIRA et al., 1996). In this study, the fertilizer Bokashi had no beneficial effects compared with Fishfertil ${ }^{\circledR}$, which reduced the incidence of downy mildew on plants that were cultivated by lateral stem bending. From the results obtained in this study, we can infer that the type of organic fertilizer and method of use must also be taken into account with regard to the prevention of disease.

As shown in Table 5, there was no significant difference between treatments when an additional treatment was assessed. The results show that the mixture of biofertilizers also did not influence the evaluation of powdery and downy mildew.

Plants grown with a balanced supply of nutrients had a greater resistance to disease. This relationship is based on the fact that the faster the growth, the better their ability to compensate for loss of photosynthetic compounds, or leaf and root area during infection. Also in most fungal diseases, the germination of spores on leaves and roots is stimulated by the presence of exudates. The composition of exudates depends on the cell concentration and the corresponding diffusion gradient. The concentrations of sugars and amino acids are high in the leaves with nutritional deficiencies, such as potassium. The concentration of amino acids is also high when nitrogen is supplied in excess (MARSCHNER, 1995). Based on this information, our findings support the idea that the incidence and severity of powdery and downy mildew on rosebushes occurred because of the different nutrient composition of organic fertilizers used, which either favored or hindered the development of these fungal diseases.

\section{CONCLUSION}

Under the experimental conditions of this study, we concluded that for the 'Osiana' rose, the incidence and severity of disease were not influenced by fertilizer management or the plant training methods. For the 'Carola' rose, different types of fertilizer resulted in different responses depending on the training method used, with the biofertilizer Fishfertil ${ }^{\circledR}$ reducing incidence of powdery mildew when applied to plants that had the lateral stem bending treatment.

\section{ACKNOWLEDGEMENTS}

The authors would like to thank FAPEMIG, FINEP, Capes, and the CNPq for supporting research and for awarding scientific initiation and post-doctorate grants.

\section{REFERENCES}

ALMEIDA, E.F.A.; PIVETTA, K.F.L.; PAIVA, P.D.O.; ICHINOSE, J.G.S.; GIMENES, R.; LESSA, M.A.; REIS, S.N.; CARVALHO, L.M.; RIBEIRO, M.N.O. Rosa. In: Produção de Flores de Corte, v.2, 2014. 819p.

CUNHA, A.O.; SILVA, V.F.; SILVA, A.P.; ALMEIDA, F.A.; ARAÚJO, G.B.; BRUNO, G.B. Intensidade de pragas e doenças em feijão macassar cultivado em sistemas orgânicos e convencionais. Horticultura Brasileira, Brasília, v.18, p.440-442, 2000.

GOMES, L.F.S. Produção comercial de rosas de corte no Distrito Federal. Boletim Técnico: UPIS - Faculdades Integradas, 2005, 29p.

LIETH, J.H.; KIM, S.H. Effects of shoot-bending in relation to root media on cut flower production in roses. Acta Horticulturae, Davis, v.547, p.303-310, 2001.

MARTINEZ, C.M.T. Introdução de novas cultivares de rosas no Brasil. Revista Brasileira de Horticultura Ornamental, Campinas, v.12, n.2, p.71-74, 2007.

MARSCHNER, H. Mineral nutrition of higher plants. London: Academic Press, 1995. 889p.

MEDEIROS, M.B.; WANDERLEY, P.A.; FRANKLIN, F.; FERNANDES, F.S.; ALVES, G.R.; DANTAS, P.; CORDÃO, R.P.; XAVIER, W.M.R.; LEAL NETO, J.S. Uso de biofertilizantes líquidos no manejo ecológico de pragas agrícolas. 2012. Disponível em: <www.prac. ufpb.br/anais/meae/Anais.../BIOFERTILIZANTES.doc $>$. Acesso em: 16 de janeiro de 2012.

PASINI, C.; D'AQUILA, F.; CURIR, P.; GULLINO, M.L. Effectiveness of antifungal compounds against rose powdery mildew (Sphaerotheca pannosa var. rosae) in glasshouses. Crop Protection, v.16, n.3, p.251-256, 1997.

PATRIQUIN, D.G.; BAINES, D.; ABBOUD, A. Soil fertility effects on pests and diseases. In: COOK, H. F.; LEE, H. C. (Eds.). Proceedings of the Third International Conference on Sustainable Agriculture. London: Wye College Press,. p.161-174, 1993

PEDINI, S. Apostila de Cafeicultura Orgânica. 2000. Disponível em: <http://www.planetaorganico.com.br/ cafepedini.htm $>$. Acesso em: 29 de janeiro de 2012.

PEREIRA， J.C.R.; ZAMBOLIM， L.; VALE， F.X.R.; CHAVES, G.M. Compostos orgânicos no controle de doenças de plantas. In: LUZ, W.C.; FERNANDES, J.M.; PRESTES; A.M.; PICININI, E.C. (Eds.) Revisão Anual de Patologia de Plantas. Passo Fundo: RAPP, v.4, p.353-379, 1996.

SHANER, G.; FINNEY, R.F. The effect of nitrogen fertilization on the expression of slow-mildewing resistance 
in knox wheat. Phytopathology, v.67, n.8, p.1051-1056, 1977.

SOUZA, J.L. Agricultura Orgânica. Vitória: EMCAPA. 1998. 176p.

VENZON, M.; ROSADO, M.C.; PINTO, C.M.F.; DUARTE, V.S.; EUZÉBIO, D.E.; PALLINI, A. Potencial de defensivos alternativos para o controle do ácaro-branco em pimenta "Malagueta". Horticultura Brasileira. Brasília, v.24, n.2, p.224-227, 2006.
VIDA, J.B.; ZAMBOLIM, L.; TESSMANN, D.J.; BRANDÃO FILHO, J.U.T.; VERZIGNASSI, J.R.; CAIXETA, M.P. Manejo de doenças de plantas em cultivo protegido. Fitopatologia Brasileira, Brasília, v.29, n.4, p.355-372, 2004.

ZAMBOLIM, L.; COSTA, H.; LOPES, C.A.; VALE, F.X.R. Doenças de hortaliças em cultivo protegido. Informe Agropecuário, Belo Horizonte, v.20, p.114-125, 1999. 
